Original paper

\title{
OPTIMIZATION OF PROTEIN FEED FERMENTATION PROCESS FOR SUPPLEMENTATION OF APIS MELLIFERA HONEYBEES
}

\author{
Erica G. Lima' \\ Rejane S. Parpinelli² \\ Pedro R. Santos ${ }^{2}$ \\ Alexandre S. B. Azevedo ${ }^{3}$ \\ Maria J. Sereia ${ }^{4}$ \\ Vagner A. Arnaut de Toledo5* \\ ${ }^{1}$ Federal University of Sergipe, Aracaju, Brazil \\ 2Maringa State University, Maringá, Brazil \\ ${ }^{3}$ Federal Institute of Education, Science and Technology of São Paulo, Capivari, \\ Brazil \\ ${ }^{4}$ Federal Technological University of Parana, Campo Mourão, Brazil \\ 5 Maringa State University, Maringá, Brazil \\ *corresponding author: vagner_abelha@yahoo.co.uk \\ Received: 05 October 2018; accepted 17 November 2019
}

Abstract

An alternative to natural food shortage for honeybees is the provision of supplements. The objective of this research was to develop a method with ideal conditions for the fermentation of a protein supplement for honeybees. The microorganisms used were Lactobacilli, Bifidobacteria and Saccharomyces and the inulin prebiotic. There was an increase in lactic acid and a decrease in pH over a five-day fermentation period. The amount of acid bacteria present was 108-109 CFU/g of supplement. In the first phase the temperature and the humidity had significantly affected the fermentation but the variables inulin and probiotic didn't. In the second phase, the lower temperatures and higher humidity produced the best effects on the fermentative responses. It was concluded that an ideal environment with temperature, humidity, inulin and probiotics could be created which allowed the fermentation of the protein supplement in five days obtaining final product fermentative characteristics close to bee bread.

Keywords: Bifidobacteria, inulin, lactic acid, Lactobacilli, probiotic, Saccharomyces

\section{INTRODUCTION}

The assimilation of nutrients is fundamental for the growth and development of a honeybee colony (Brodschneider \& Crailsheim, 2010). The main nutrients for honeybees present in pollen and nectar are carbohydrates, proteins, lipids, vitamins, minerals and water (Manning et al., 2007). Honeybees convert nectar into honey and pollen into bee bread, allowing the availability of nutritional content (Altaye et al., 2010).

Bee bread is the most nutritious food of honeybees and the main source of protein. The pollen collected by the foragers is stored in cells and mixed with honey. This mixture undergoes physical, chemical and microbiological processes with the action of enzymes, microorganisms, humidity and temperature. In about two weeks the pollen is fermented (Nagai et al., 2005). In this process, the yeast Saccharomyces cerevisiae consumes oxygen promoting an anaerobic environment, favoring bacteria growth ( $\mathrm{Hu}$ et al., 2008). Bacteria cause reduction in $\mathrm{pH}$ and acidification of medium, mainly through the production of lactic acid (Leroy \& Vuyst, 2004). An antimicrobial action is observed in bee bread's upper layer and higher values of total phenolics in the lower layer (Podrižnik \& Božič, 2015). Microorganisms are not only involved in the production and preservation of food, honey and bee bread, but also important for honeybee health (Vásquez et al., 2012; Raymann, Shaffer, \& Moran, 2017). To understand these benefits, such factors as microorganism composition 
and quantification, honeybee genetics and physiology and environmental factors must be known (Engel et al., 2016).

The intense transformation of agriculture, degradation of natural habitats and creation of monocultures alter the abundance, transmission rate and survival of the beneficial microorganisms that inhabit a place and affect the adequate supply of nutrients required by honeybees (Nicholls \& Altieri, 2012; Anderson et al., 2013). As a result, the nutrition and immunity of a colony is compromised because even it is not sick does not mean that it is healthy. Healthy colony should be disease-free and above all, well-nourished and capable of perpetuation (Brodschneider \& Crailsheim, 2010).

An alternative to natural food shortage for honeybees is the provision of supplements. Research related to this supply shows good results in the development and colony maintenance, increased royal jelly production and honeybee's longevity, decreased mortality rate, increased protein quantification in hemolymph and financial viability (Pereira et al., 2006; Cappelari et al., 2009; De Jong et al., 2009; Sereia et al., 2010a,b; 2013; Morais et al., 2013a, b). Usually the substitutes are not fermented and do not contain specific microflora. The administration of probiotic preparations with or without prebiotics has a positive effect on honeybees (Evans \& Lopez, 2004; Kaznowski et al., 2005; Kazimierczak-Baryczko \& Szymaś, 2006; Szymaś, Łangowska, \& KazimierczakBaryczko, 2012; Pătruică, \& Mot, 2012; Pătruică et al., 2012; Pătruică \& Hutu, 2013). Their social lifestyle facilitates the inoculation and dissemination of probiotics in the colonies (Engel \& Moran, 2013). The maintenance of these microorganisms, mainly Bifidobacteria and Lactobacilli, can be maintained with the supply of such prebiotics as inulin (Gallina et al., 2011).

Araneda et al. (2014) stated that it is possible to develop a supplement in the laboratory, provided that it has constituent elements similar to bee bread. To produce a fermented supplement, one should think not only of the ingredients of the formulation, but also of the microorganisms used and the method to be employed. Microor- ganism activity is affected by such factors as available water, temperature, oxygen, $\mathrm{pH}$ and available nutrients (Siqueira, 1995). Therefore, the development method must encompass these factors to get an ideal end product. Due to the necessity and the possibility of creating an improved supplement this experiment's objective was to develop a method with optimal conditions to ferment a protein supplement for honeybees with ideal fermentative characteristics similar to bee bread.

\section{MATERIAL AND METHODS}

The analysis was carried out at the Laboratory of Service Provision of the Federal Technological University of Parana at Campo Mourão in the State of Рarana $\left(24^{\circ} 02^{\prime} 44^{\prime \prime} S, 52^{\circ} 22^{\prime} 09^{\prime \prime} W\right)$ between June and December 2016.

\section{Solutions}

Himedia Malt Extract Powder Refined Broth; De Man broth, Rogosa and Sharpe LactobacilIus from Acumedia (MRS); De Man agar, Rogosa and Sharpe Lactobacillus agar from MicroMed ${ }^{\oplus}$ (MRS); Streptococcus thermophilus agar (ST); Acumedia Dextrose (BDA) potato agar and peptone water.

\section{Protein supplement}

The supplement used was developed by Sereia et al. (2013) and composed of isolated soy protein, linseed oil, palm oil, brewing yeast, refined sugar, honey, pollen, soy lecithin and vitamins. It was modified with the elimination of the microbial load present in the pollen following the method described by Fuenmayor, Quicazán, \& Figueroa (2011). In sterilized 200 $\mathrm{mL}$ glass vials, a mixture of pollen: distilled water (2:1) autoclaved at $121^{\circ} \mathrm{C}$ for fifteen minutes was added. After sterilization, the supplement ingredients were weighed, homogenized and sieved. The percentage moisture content of the supplement was determined following the method described by the Adolfo Lutz Institute (2008). It was used for the analysis of humidity, scale and sterilization oven and drying. 


\section{Variables analyzed}

Analyzes prior to the experiment were performed to verify which variables could contribute positively to the fermentation of the protein supplement. It was observed that temperature, moisture, possible probiotics (Fuenmayor, Quicazán, \& Figueroa, 2011; Ríos et al., 2012; Araneda et al., 2014; Ríos et al., 2014) and inulin (Vamanu et al., 2010) would be important variables. Possible probiotics had only efficient activity when used together. Probably the presence of one species favors the development and activity of other species. This was due to symbiosis between the different microorganisms and when separated showed no efficient activity (Gandra \& Gandra, 2007; Ellis \& Hayes, 2009).

So, the variables analyzed to verify their effects in the fermentation were:

a) Temperature: controlled in a bacteriological stove.

b) Moisture: determined according to the method described by the Adolfo Lutz Institute (2008). Subsequently, the global equation for mass balance was performed.

c) Prebiotic: Orafti ${ }^{\oplus}$ GR inulin was the prebiotic used. The weighing was performed in a precision analytical scale. After the inulin was added to the supplement, the tests underwent afinal sterilization remaining for fifteen minutes in a sterilization oven and drying at $90^{\circ} \mathrm{C}$.

d) Microorganisms potentially probiotic: Streptococcus thermophilus (strain BV-YOG 03/2 Bela Vista ${ }^{\circ}$ ), Lactobacillus delbrueckii spp. Bulgaricus (strain YF-L811 Chr. Hansen ${ }^{\circ}$ ), Bifidobacterium animalis spp. lactis (strain BLC $1 \mathrm{SACCO}^{\circ}$ ), and Lactobacillus casei shirota isolated from commercial fermented beverages and Saccharomyces cerevisiae (Fleischmann ${ }^{\circ}$ ).

All the microorganisms used in this study are naturally found in bee bread, and the amount depends on the floral origin. Pollen fermentation begins with the activity of yeast. Subsequently the fermentation process continues with the aerobic lactic acid bacteria and ends with the activity of the anaerobic lactic acid bacteria (Gilliam, 1979). These microorganisms were inoculated on average at $2 \%$ in the activation broth (Ríos et al., 2012). The percentage in each treatment was defined by the statistical program.

\section{Activation of microorganisms}

The microorganisms used were Streptococcus thermophilus (strain BV-YOG 03/2 Bela Vista ${ }^{\circ}$ ): $2 \mathrm{~g} / 100 \mathrm{~mL}$ of broth; Lactobacillus delbrueckii spp. Bulgaricus (strain YF-L811 Chr. Hansen $\left.{ }^{\circ}\right)$ : $2 \mathrm{~g} / 100 \mathrm{~mL}$ of broth; Bifidobacterium animalis spp. lactis (strain BLC 1 SACCO $): 2 \mathrm{~g} / 100 \mathrm{~mL}$ of broth; Lactobacillus casei shirota isolated from commercial fermented beverages: $10 \mathrm{~mL}$ / $100 \mathrm{~mL}$; and Saccharomyces cerevisiae (Fleischmann $\left.{ }^{\circ}\right): 2 \mathrm{~g} / 100 \mathrm{~mL}$ of broth.

Activation was performed in specific broths previously sterilized in an autoclave at $121^{\circ} \mathrm{C}$ for fifteen minutes. The yeast in Broth Malt Extract Powder was refined for thirty minutes at $30 \pm$ $2^{\circ} \mathrm{C}$ without being stirred in a metabolic bath. The bacteria producing lactic acid were kept in MRS broth for 72 hours at $37 \pm 2^{\circ} \mathrm{C}$ in a bacteriological oven. When all probiotic cultures were active, the microorganisms were counted.

\section{Counting of microorganisms}

The method used was inoculation in triplicate. Cultures active in a specific broth formed the $10^{-1}$ dilution. After the initial dilution, consecutive serial dilutions were made up to $10^{-10}$, withdrawing $1 \mathrm{~mL}$ of the initial dilution to $9 \mathrm{~mL}$ of $0.1 \%$ peptone water. Of the desired dilutions, $1 \mathrm{~mL}$ was pipetted to sterile Petri dishes. To each plate, $15 \mathrm{~mL}$ of the MRS agar medium was added for the growth of Lactobacilli and Bifidobacteria, ST agar was added for Streptococci. The acidified agar BDA was used for yeast Saccharomyces cerevisiae.

All media were pre-melted and cooled to 44 $\pm 2^{\circ} \mathrm{C}$. The plates were manually moved in an eight-fold format for the uniform mixture of the inoculum in the agar. After solidification, they were incubated in a bacteriological oven. The plates with the MRS agar medium were kept in anaerobic atmosphere generator with an oxygen-absence indicator for 72 hours at $37 \pm 2{ }^{\circ} \mathrm{C}$. The plates with ST agar medium were kept in aerobiosis wrapped in 24-hour film paper at 37 
$\pm 2{ }^{\circ} \mathrm{C}$. The plates with BDA medium were kept in aerobiosis wrapped with film paper for 72 hours at $25 \pm 2{ }^{\circ} \mathrm{C}$. After incubation, the number of colony-forming units (CFU/g) was counted. After the bacteria were counted, they were pipetted into the supplement according to the needs of each trial. The amount of probiotic used in Trial 1, 2, 3 and 4 was $7.5 \%, 12.5 \%$ in Trial 5, 6, 7, and 8 while in Trial 9, 10, 11 and 12 was 10\%. With $7.5 \%$ of probiotic only $1.5 \%$ of each species was inoculated, $2.5 \%$ of each species was inoculated when the amount of probiotic was $12.5 \%$ and when the probiotic was $10 \%, 2.0 \%$ of each species was inoculated.

\section{Fermentation of the protein supplement}

Inside the laminar flow hood the probiotic mix was inoculated into $100 \mathrm{~g}$ of the supplement with values according to the experimental design. The probiotic supplement was kept in a $200 \mathrm{~mL}$ glass and kept in anaerobic atmosphere generator with an oxygen-absence indicator for five days in a bacteriological oven.

\section{Fermentation Responses}

In the first experimental planning, the variables' effects on $\mathrm{pH}$ and lactic acid were verified on the first and fifth days of fermentation. In the second experimental planning, the variables' effects on $\mathrm{pH}$, lactic acid production and viable lactic acid bacteria on the last day of fermentation were verified.

a) $\mathrm{pH}$ : followed the method described by the Adolfo Lutz Institute (2008). Samples were weighed on an analytical scale. The $\mathrm{pH}$ meter was calibrated and operated according to the manufacturer.

b) Lactic acid: followed by the method described by the Adolfo Lutz Institute (2008). An analytical scale was used for the weighing. The contents were shaken on a magnetic stirrer with controlled shaking at $20 \mathrm{rpm}$. Colors of the samples interfered with the visualization of the phenolphthalein turning point, so a potentiometric titration was used. For this, the $\mathrm{pH}$ meter was immersed in the samples. The lactic acid produced was calculated following the equation: Lactic acid produced $=$ final lactic acid - initial lactic acid.

c) Counting of viable acid bacteria: The method described by Siqueira (1995) was followed. In the laminar flow hood, $25 \mathrm{~g}$ of the fermented supplement was added to $225 \mathrm{~mL}$ of $0.1 \%$ peptone water, forming the dilution $10^{-1}$. From this dilution, successive dilutions up to $10^{-10}$ were carried out. The MRS agar was used and kept in anaerobic atmosphere generator with an oxygen-absence indicator. After the bacteria were counted, all presented values were above $1 \times 10^{8}$ (CFU/g), an ideal concentration to be considered probiotic (Gallina et al., 2011).

\section{Lyophilization}

The fermented protein supplement was placed in Petri dishes covered with perforated aluminum foil and frozen in a freezer at $-20^{\circ} \mathrm{C}$ by 24 hours. Drying took place in a freeze dryer at $-57^{\circ} \mathrm{C}$ for 96 hours. After Iyophilization, the supplement was packed in $100 \%$ polyethylene plastic bags with hermetic closure, hand crushed, sieved and stored in laminated packaging. A sealing machine was used for the closure.

\section{Statistical analysis}

The statistic used was according to Rodrigues \& lemma (2009) using the Software Protimiza Experimental Design. Twenty-four trials were performed in total to identify the optimized fermented protein supplement.

In the first stage of the experiment, twelve Fractional Factorial Planning tests were used for five days to identify which of the four independent variables with four central points $\left(2^{4-1}+4 p c\right)$ influence the fermentation and thus define the next factorial to be adopted. The samples were temperature $\left(35.00^{\circ} \mathrm{C}, 40.00^{\circ} \mathrm{C}\right.$ and $45.00^{\circ} \mathrm{C}$ ), moisture $(36.00 \%, 56.00 \%, 76.00 \%)$, probiotic $(7.50 \%, 10.00 \%$, and $12.50 \%)$ and inulin $(1.00 \%$, $2.00 \%, 3.00 \%)$.

To identify the main variable responsible for fermentation, Central Compound Rotational Delineation was performed for two independent variables with four extremes and four central points $\left(2^{2}+4\right.$ axials $\left.+4 p c\right)$, totaling 12 trials. Temperature $\left(38.96^{\circ} \mathrm{C}, 40.00^{\circ} \mathrm{C}, 42.50^{\circ} \mathrm{C}\right.$, $45.00^{\circ} \mathrm{C}$ and $\left.46.04^{\circ} \mathrm{C}\right)$, moisture $(51.86 \%$, 
$56.00 \%, 66.00 \%, 76.00 \%$ and $80.14 \%$ ) were used. The level of significance was set at $5 \%(p<0.05)$. The results were evaluated by analysis of variance and regression analysis.

\section{RESULTS}

In the treatments after fermentation, there was an increase in lactic acid and, consequently, a reduction in $\mathrm{pH}$ (Tab. 1). pH values after fermentation ranged from $3.58 \pm 0.01$ to $5.35 \pm$ 0.02 . The highest $\mathrm{pH}$ after fermentation of the product was observed in the Trial 1. The effects of the variables on $\mathrm{pH}$ can be observed in Fig. 1. A significant negative effect $(p<0.10)$ of curvature (-1.68), moisture (0.18), and temperature (1.56) was observed. Probiotic and inulin showed no significant effects.

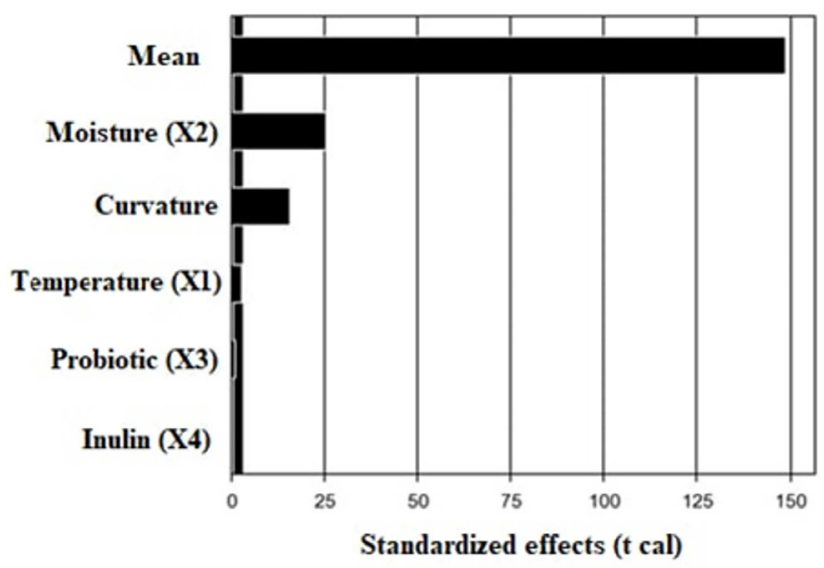

Fig. 1. Standardized effects (tcalc) of the variables: mean, moisture, curvature, temperature, probiotic and inulin on $\mathrm{pH}$.

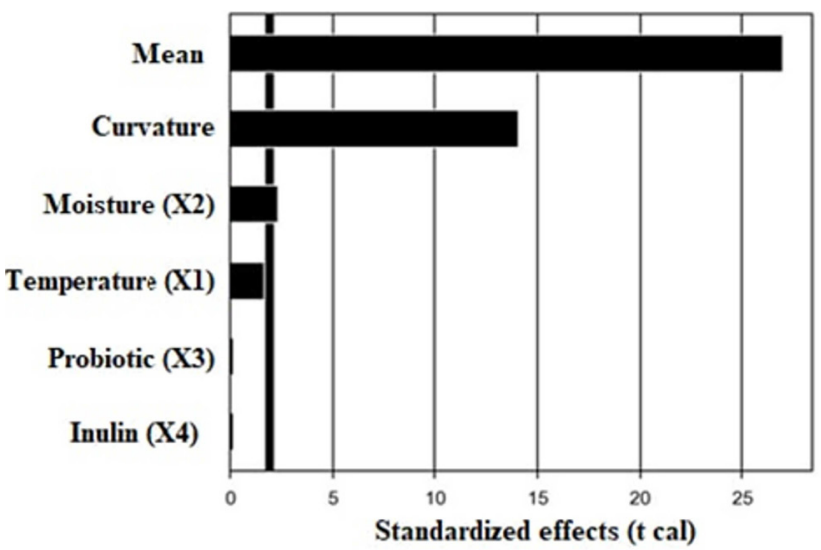

Fig. 2. Standardized effects (tcalc) of the variables: mean, moisture, curvature, temperature, probiotic and inulin on lactic acid.
The percentage of lactic acid after fermentation ranged from $1.40 \pm 0.05 \%$ to $3.18 \pm 0.03 \%$. The lowest lactic acid value occurred under the conditions of Trial 1 and 2 (Tab. 1). Curvature and moisture presented significant effects $(p<0.10)$ with values of 2.85 and 0.28 , respectively (Fig. 2). Because the amount of moisture was significantly greater, the percentage of lactic acid in the product also increased. Temperature, probiotic and inulin were not significantly affected.

From these results the next planning was determined to eliminate the lower temperature $\left(35^{\circ} \mathrm{C}\right)$ and the lower moisture $(36 \%)$, and fix the probiotic and inulin variables in the central values, $10 \%$ and $2 \%$, respectively.

$\mathrm{pH}$ ranged from $3.49 \pm 0.01$ to $3.96 \pm 0.01$. The lowest $\mathrm{pH}$ value was observed under the

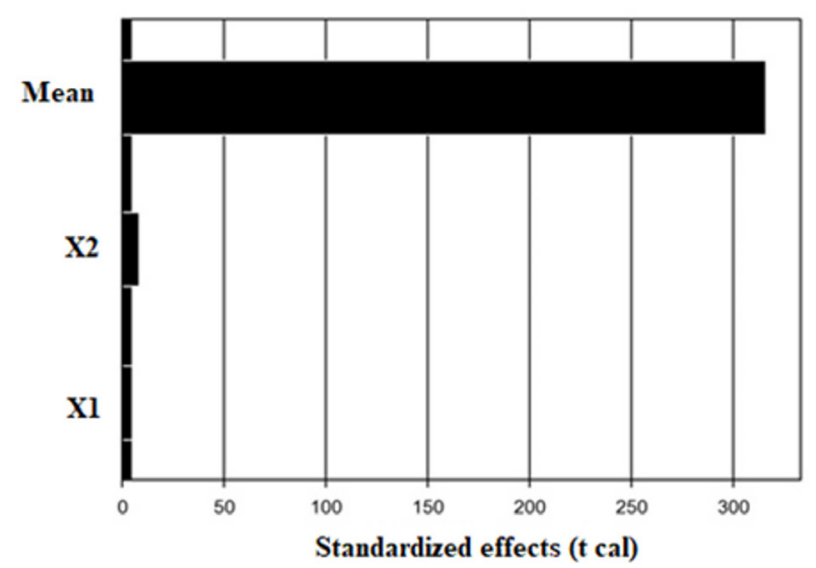

Fig. 3. Standardized effects (tcalc) of the variables: mean, temperature and moisture on $\mathrm{pH}$.

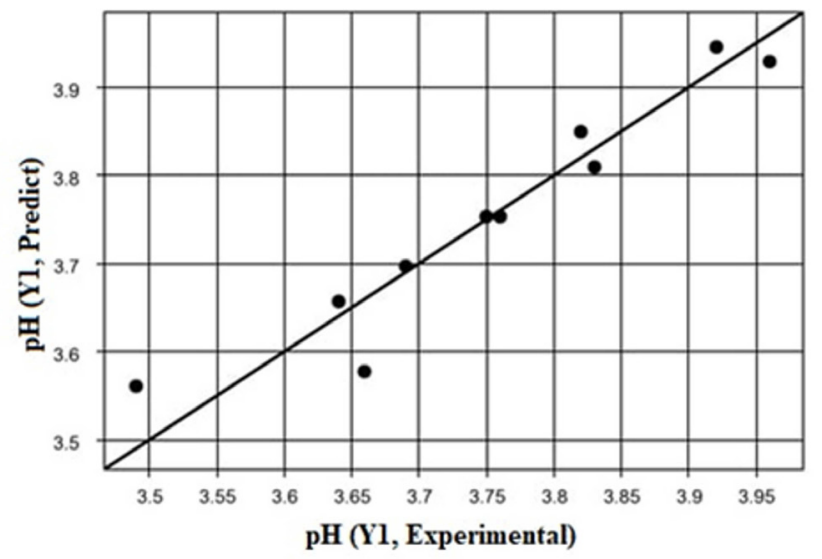

Fig. 4. $\mathrm{pH}$ behavior with experimental values $\mathrm{x}$ predicted by the model. 
conditions of Trial 3 (Tab. 2). In equation 1, the effects on $\mathrm{pH}$ (Fig. 3), while pH behavior was $\mathrm{pH}$ predicted by the model is presented as a observed in Fig. 4.

function of the coded variables. The tempera- (Eq. 1): $Y_{1}=3.75+0.07 X_{1}-0.12 X_{2}$ ture and moisture had potentially important The adjusted model of the line was significant

Table 1.

Experimental design matrix with the variables temperature (X1), moisture (X2), probiotic (X3) and inulin (X4) for protein supplement fermentation and mean values (standard deviation) of the responses $(n=3) \mathrm{pH}(Y 1)$ and lactic acid $(Y 2)$ in the first (1st day) and fifth day ( $5^{\text {th }}$ day) of fermentation

\begin{tabular}{cccccccccc}
\hline \multicolumn{9}{c}{ Variables } \\
\hline Trial & $\begin{array}{c}\text { Tem- } \\
\text { perature } \\
\left({ }^{\circ} \mathrm{C}\right)\end{array}$ & $\begin{array}{c}\text { Moisture } \\
(\%)\end{array}$ & $\begin{array}{c}\text { Probiotic } \\
(\%)\end{array}$ & $\begin{array}{c}\text { Inulin } \\
(\%)\end{array}$ & $\mathrm{pH}$ & $\mathrm{pH}$ & $\begin{array}{c}\text { Lactic acid } \\
(\%)\end{array}$ & $\begin{array}{c}\text { Lactic acid } \\
(\%)\end{array}$ \\
\hline & & & & & $1^{\text {st }}$ day & $5^{\text {th }}$ day & $1^{\text {st }}$ day & $5^{\text {th }}$ day \\
\hline 1 & 35.00 & 36.00 & 7.50 & 1.00 & $5.48(0.03)$ & $5.35(0.02)$ & $1.33(0.02)$ & $1.40(0.05)$ \\
2 & 45.00 & 36.00 & 7.50 & 3.00 & $5.31(0.03)$ & $5.28(0.05)$ & $1.39(0.02)$ & $1.40(0.05)$ \\
3 & 35.00 & 76.00 & 7.50 & 3.00 & $5.62(0.01)$ & $3.88(0.01)$ & $0.47(0.01)$ & $1.54(0.01)$ \\
4 & 45.00 & 76.00 & 7.50 & 1.00 & $5.67(0.01)$ & $3.58(0.01)$ & $0.43(0.01)$ & $2.00(0.03)$ \\
5 & 35.00 & 36.00 & 12.50 & 3.00 & $5.48(0.01)$ & $5.34(0.01)$ & $1.35(0.01)$ & $1.49(0.02)$ \\
6 & 45.00 & 36.00 & 12.50 & 1.00 & $5.37(0.02)$ & $5.34(0.01)$ & $1.35(0.01)$ & $1.45(0.01)$ \\
7 & 35,00 & 76.00 & 12.50 & 1.00 & $5.38(0.02)$ & $3.98(0.01)$ & $0.63(0.01)$ & $1.48(0.03)$ \\
8 & 45.00 & 76.00 & 12.50 & 3.00 & $5.28(0.01)$ & $3.62(0.01)$ & $0.51(0.01)$ & $1.83(0.01)$ \\
9 & 40.00 & 56.00 & 10.00 & 2.00 & $5.38(0.05)$ & $3.71(0.02)$ & $0.87(0.02)$ & $2.89(0.12)$ \\
10 & 40,00 & 56.00 & 10.00 & 2.00 & $5.39(0.10)$ & $3.70(0.03)$ & $0.90(0.04)$ & $2.91(0.05)$ \\
11 & 40.00 & 56.00 & 10.00 & 2.00 & $5.37(0.07)$ & $3.70(0.01)$ & $0.90(0.03)$ & $3.18(0.03)$ \\
12 & 40.00 & 56.00 & 10.00 & 2.00 & $5.46(0.06)$ & $3.72(0.01)$ & $0.90(0.02)$ & $3.02(0.01)$ \\
\hline
\end{tabular}

Table 2.

Experimental design matrix with the variables temperature (X1), moisture (X2) and mean values (standard deviation) of the responses $(n=3) \mathrm{pH}(\mathrm{Y} 1)$, lactic acid produced $(\mathrm{Y} 2)$ and lactic bacteria

(Y3) after fermentation of the protein supplement

\begin{tabular}{cccccc}
\hline \multicolumn{4}{c}{ Variables } & \multicolumn{4}{c}{ Responses } \\
\hline Trial & Temperature $\left({ }^{\circ} \mathrm{C}\right.$ ) & Moisture $(\%)$ & $\mathrm{pH}$ & Lactic acid $(\%)$ & Lactic bacteria $\left(\right.$ CFU g $\left.{ }^{-1}\right)$ \\
\hline 1 & 40.00 & 56.00 & $3.83(0.01)$ & $1.47(0.01)$ & $2.4(0.1) \times 10^{9}$ \\
2 & 45.00 & 56.00 & $3.92(0.01)$ & $1.33(0.01)$ & $3.3(0.3) \times 10^{8}$ \\
3 & 40.00 & 76.00 & $3.49(0.01)$ & $1.56(0.02)$ & $3.5(0.2) \times 10^{9}$ \\
4 & 45.00 & 76.00 & $3.69(0.01)$ & $1.08(0.01)$ & $2.8(0.1) \times 10^{8}$ \\
5 & 38.96 & 66.00 & $3.64(0.01)$ & $1.66(0.02)$ & $3.8(0.1) \times 10^{9}$ \\
6 & 46.04 & 66.00 & $3.82(0.01)$ & $1.36(0.01)$ & $3.5(0.1) \times 10^{8}$ \\
7 & 42.50 & 51.86 & $3.96(0.01)$ & $1.38(0.03)$ & $2.1(0.2) \times 10^{9}$ \\
8 & 42.50 & 80.14 & $3.66(0.01)$ & $1.06(0.01)$ & $2.8(0.1) \times 10^{8}$ \\
9 & 42.50 & 66.00 & $3.76(0.01)$ & $1.34(0.02)$ & $3.2(0.1) \times 10^{8}$ \\
10 & 42.50 & 66,00 & $3.76(0.01)$ & $1.31(0.03)$ & $3.1(0.2) \times 10^{8}$ \\
11 & 42.50 & 66.00 & $3.75(0.01)$ & $1.35(0.06)$ & $3.6(0.1) \times 10^{8}$ \\
12 & 42.50 & 66.00 & $3.75(0.01)$ & $1.36(0.13)$ & $3.7(0.1) \times 10^{8}$ \\
\hline
\end{tabular}




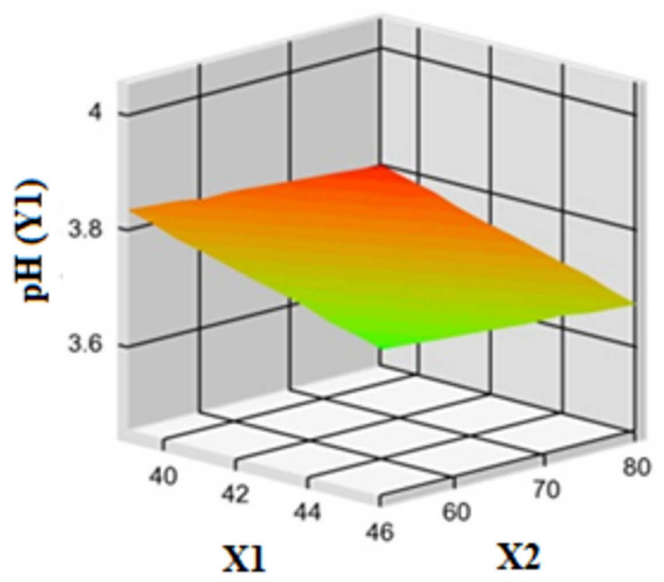

Fig. 5. Response surface for the $\mathrm{pH}$ response $(\mathrm{Y} 1)$ as a function of temperature (X1) and moisture (X2).

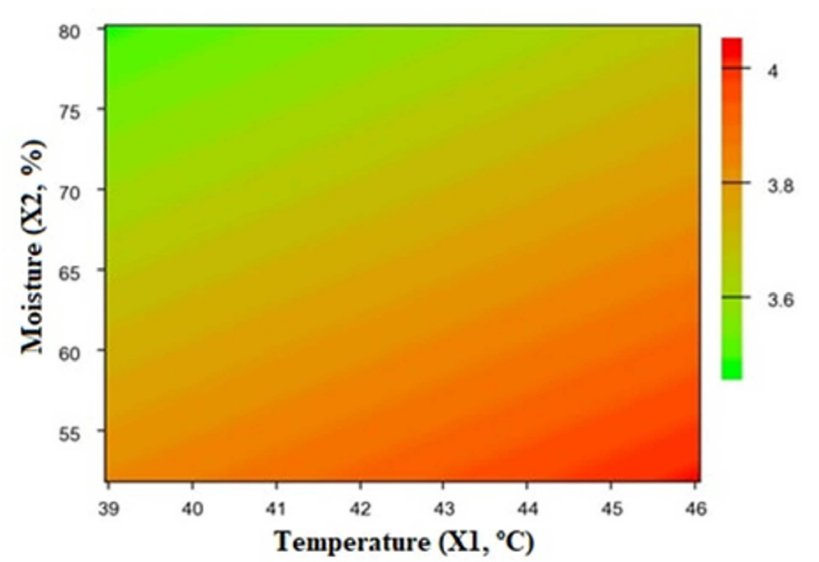

Fig. 6. Contour curve for the $\mathrm{pH}$ response $(\mathrm{Y} 1)$ as a function of temperature (X1) and moisture (X2).

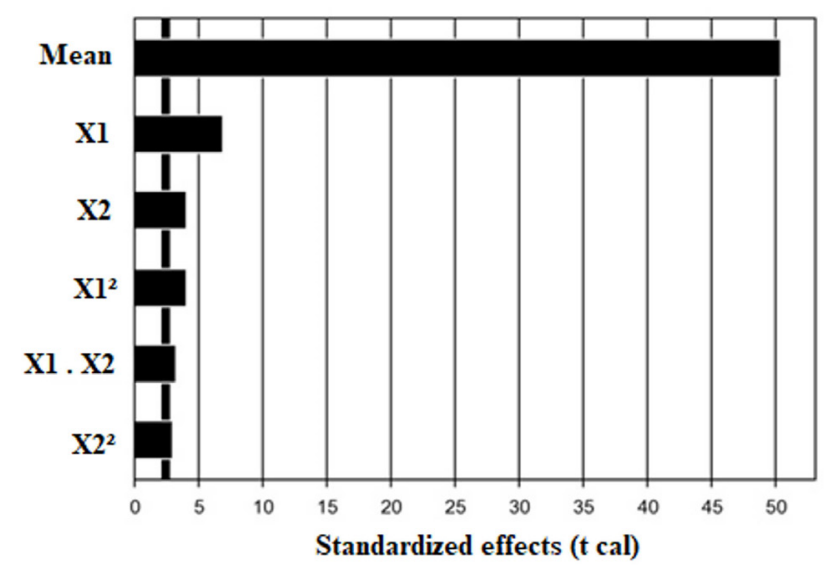

Fig. 7. Standardized effects (tcalc) of the variables: mean, temperature, moisture on lactic acid production.

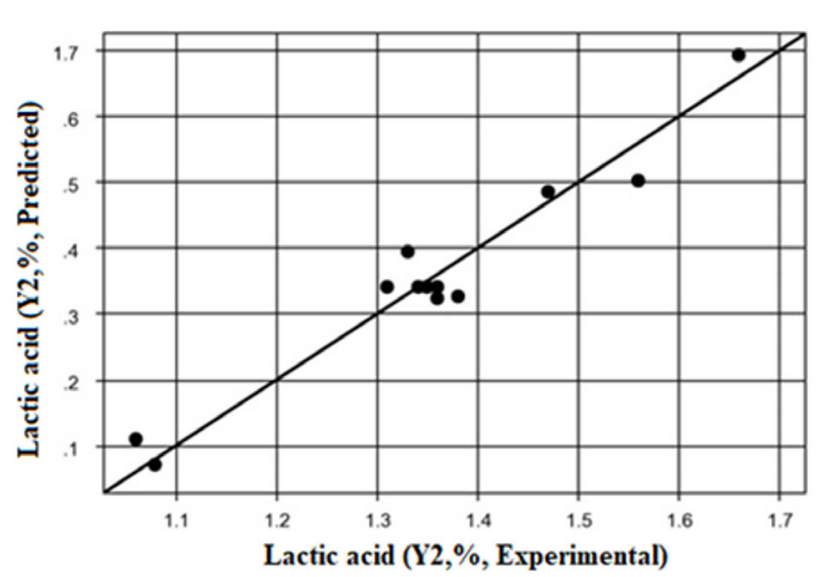

Fig. 8. Behavior of the lactic acid production with experimental values $x$ predicted by the model.

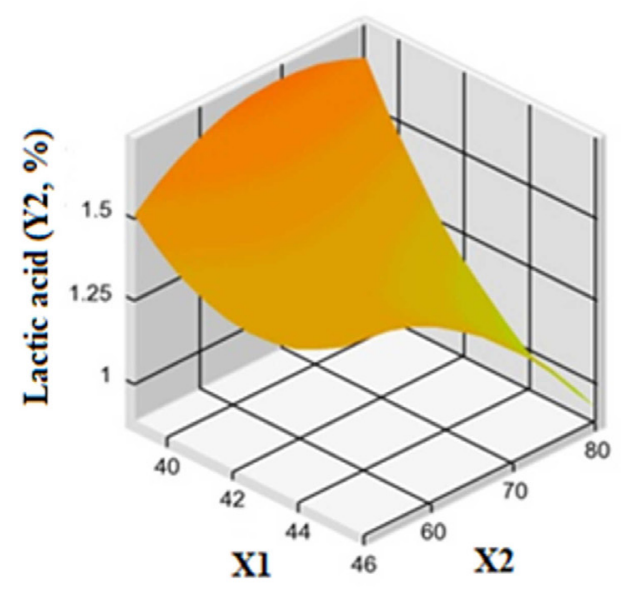

Fig. 9. Response surface (A) for the response of lactic acid production (Y2) as a function of temperature (X1) and moisture (X2).

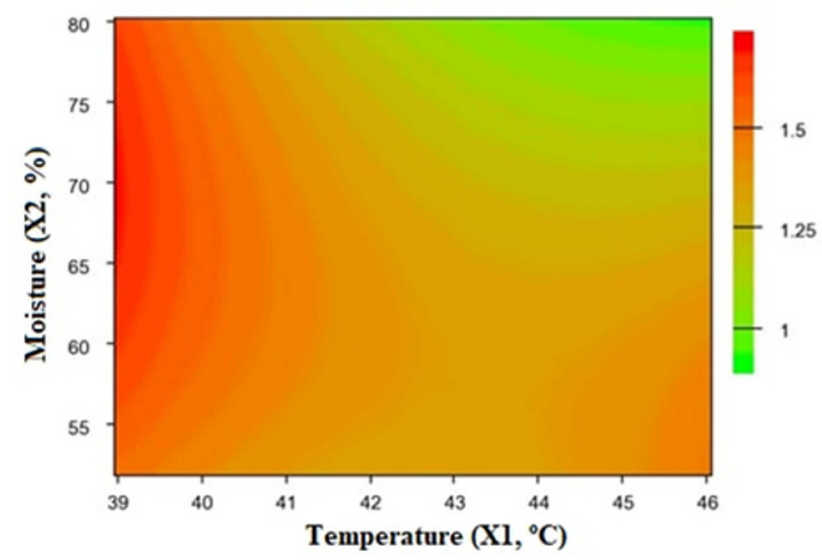

Fig. 10. Contour curve for the response of lactic acid production (Y2) as a function of temperature (X1) and moisture (X2). 
at the $5 \%$ level. The existence of the behavior presented a variation explained by adjusted coefficient of determination $\mathrm{R}^{2}=91.36 \%$. The effects of temperature and humidity on the $\mathrm{pH}$ response can be seen in Fig. 5 (response surface) and Fig. 6 (contour curve). There was a decrease in the $\mathrm{pH}$ value with low temperature and high moisture.

Lactic acid production ranging from $1.06 \pm 0.01 \%$ to $1.66 \pm 0.02 \%$ was higher for the conditions of Trial 5 (Tab. 2). In equation 2, lactic acid production predicted by the model is presented as a function of the coded variables. The temperature, moisture and interaction between the two presented potentially important effects for lactic acid production (Fig. 7). The behavior of lactic acid produced can be observed in Fig. 8. (Eq. 2): $Y_{2}=1.34-0.13 X_{1}+0.08 X_{1}^{2}-0.08 X_{2}-$ $0.06 X_{2}^{2}-0.09 X_{1} X_{2}$

The adjusted model of the line was significant at the $5 \%$ level and presented a variation explained by adjusted coefficient of determination $\mathrm{R}^{2}=94.61 \%$. The response surfaces for the lactic acid production response are presented in Figs. 9 and 10. There was an increase in lactic acid production at low temperatures and central moisture within the studied ranges.

The amount of probiotics per gram of the product ranged from $2.8 \pm 0.1 \times 10^{8}$ to $3.8 \pm$ $0.1 \times 10^{9}$ (CFU/g). Variables had no effect on this response. The adjusted model of the line was insignificant at the $5 \%$ level determining the nonexistence of behavior.

With all the analyses' result, the software provided new formulations optimized and originated through models constructed using the coded values. The formulated model accepted in this research presented the value of $38.96^{\circ} \mathrm{C}$ and $66.00 \%$ moisture to obtain an approximate $\mathrm{pH}$ of 3.66 and lactic acid production of 1.69 in the final product.

\section{DISCUSSION}

Fermentation was observed in all trials. During fermentation lactic acid increases and consequently $\mathrm{pH}$ reduces (Hu et al., 2008). Pollen was one of the supplement ingredients and, with fermentation, the exine, the microstructure which protects the pollen, can be partially destroyed and the rich nutrient content assimilated and used (Ariizumi \& Toriyama, 2011). All ingredients become bioavailable, making the fermented product more digestible (Tonheim et al., 2007) and stable, and restricting the growth of pathogenic microorganisms (Pattabhiramaiah, Reddy, \& Brueckner, 2012). The formulated supplement was fermented, providing the final product with a nutritional, protected and probiotic.

The final $\mathrm{pH}$ value of the fermented product ranged from $3.49 \pm 0.01$ to $3.96 \pm 0.01$. The $\mathrm{pH}$ in fermented diets after two weeks is 4.51 to 4.82 (Ellis \& Hayes Jr., 2009). In bee bread pH ranged from 3.8 to 4.3 (Herbert \& Shimanuki, 1978 ) and 3.93 to 4.23 (Barene, Daberte, \& Siksna, 2015) and bee bread fermented for fifteen days produced in the laboratory from 3.89 to 4.24 (Ríos et al., 2014). While in laboratory-produced fermented bee bread for twenty days $\mathrm{pH}$ ranged from 3.83 to 4.25 (Araneda et al., 2014). In pollen analyzes the $\mathrm{pH}$ ranged from 4.1 to 5.9 (Herbert \& Shimanuki, 1978) and in the dehydrated pollen 4.12 to 5.35 (Barreto, Funari, \& Orsi, 2005). pH rapidly decreased in the developed supplement during the five days of fermentation because of the active fermentation performed by the microorganisms.

Lactic acid production by fermented supplement ranged from $1.06 \pm 0.01$ to $1.66 \pm 0.02 \%$, a value close to that found in the literature. Laboratoryfermented pollen according to findings by Ríos et al. (2012) varied between $0.28 \pm 0.08 \%$ and $2.26 \pm 0.08 \%$ and findings by Ríos et al. (2014) between $0.34 \pm 0.05 \%$ and $2.00 \pm 0.07 \%$. It is difficult to compare these results because of the differences in the method of execution, substrate and microorganisms used. The microorganisms produce substances, in particular lactic acid, that acidify the substrate (Leroy \& Vuyst, 2004; Hu et al., 2008). It is appropriate to verify the adaptability and compatibility of the selected cultures to the substrate used (Saad, Cruz, \& Faria, 2011). The formulated supplement was suitable for the activity of bacteria and yeasts and, consequently, the medium was 
acidified with high lactic acid values.

An anaerobic environment was used for the fermentation of the supplement, a medium similar to the fermentation of the pollen when stored in the comb. The anaerobic condition was an essential parameter for both the rapid fermentation of the product and the temperature, and moisture significantly affected the permanence and activity of the microorganisms in the medium.

The temperature $38.96^{\circ} \mathrm{C}$ had a representative effect on the $\mathrm{pH}$ reduction and lactic acid production. Microorganisms are found over a wide temperature range; those below the minimum are inhibited and those above the maximum value do not survive. The ideal range for the activation and survival of acid lactic bacteria is comprised between $30-40^{\circ} \mathrm{C}$ (Siqueira, 1995; Gandra \& Gandra, 2007; Silva et al., 2010). The temperature set for the fermentation of the supplement is in accordance with the ideal temperature of growth and activity of the acid lactic bacteria.

Moisture at $66 \%$ used affected the fermentative responses. Hu et al. (2008) and Ríos et al. (2012) verified the existence of the relationship between high moisture, $\mathrm{pH}$ reduction and increased lactic acid, which corroborated with the results found. According Gandra \& Gandra (2007), water must be available for microorganisms to perform metabolic activities. In the fermented supplement developed, the high moisture allowed efficient activity of the microorganisms during the fermentation process.

There was no effect on the amount of inulin (1\%, $2 \%$ and $3 \%$ ) used on fermentative responses. Higher bacteria activity was observed when $1 \%$ of inulin was used in a product with characteristics close to bee bread (Vamanu et al., 2010). Honey, a natural prebiotic that stimulates growth and activity of bacteria (Vamanu et al., 2010), was one of the ingredients of the fermented supplement developed. The fermentative activity of the bacteria occurred effectively, possibly with the collaboration of $2 \%$ of inulin plus honey.

The amount of probiotic (7.50\%, 10.00\% and $12.50 \%$ ) added to the supplement had no sig- nificant effect on the fermentative responses. Mixed cultures and available substrate are important variables for fermentation, so the presence of one strain favors the development of the other (Gandra \& Gandra, 2007; Martín \& Cuenca, 2009). Ellis \& Hayes Jr (2009) used Lactobacillus bulgaricus, L. acidophilus, L. casei, L. rhamnosus, Streptococcus thermophilus and Bifidobacterium bifidum to promote fermentation of the diet and to suggest that nutritional value and product palatability improved. Therefore, the type of crop and the combination of crops to be used, Streptococcus thermophilus, Lactobacillus delbrueckii spp. bulgaricus, Bifidobacterium animalis spp. lactis, LactobacilIus casei shirota and Saccharomyces cerevisiae, interfered more in the fermentation than the used amount of $10 \%$.

The concentration higher than $10^{8} \mathrm{CFU} / \mathrm{g}$ present in the fermented supplement developed corroborates the concentration indicated for probiotic products by the National Health Surveillance Agency (2008). Commercial probiotic preparations use mean concentrations of $10^{9}$ CFU/g (Kazimierczak-Baryczko \& Szymaś, 2006; Szymaś, Łangowska, \& Kazimierczak-Baryczko, 2012). Regardless of the value added to the developed fermented supplement, the final product of all the trials presented ideal CFU/g to be considered as probiotic products. Bacteria reproduced and colonized the existing substrate in ideal amounts for the medium in which they were located.

It was possible to develop a fermented protein supplement optimized under laboratory conditions in five days. The method developed to ferment the supplement provided ideal conditions for efficient activity of the microorganisms. The developed supplement possessed fermentative properties similar to bee bread, natural food of the honeybees.

\section{ACKNOWLEDGMENTS}

The authors acknowledge the CNPq (National Council for Scientific and Technological Development), process number 311663/2014$1,479329 / 2009-5$ and 308283/2011-2 and 
Araucaria Foundation protocol number 15095 - 422/2009 for the financial support. Thanks to the Federal Technological University of Parana (UTFPR) for allowing the use of physical structures, the use of their equipment and donation of materials for the execution of the project.

\section{REFERENCES}

Agência Nacional de Vigilância Sanitária. (2008). Alimentos com alegação de propriedades funcionais e ou saúde, novos alimentos/ ingredientes, substâncias bioativas e probióticas. http://www. anvisa.gov.br/alimentos/comissoes/tecno_lista_ alega.htm. (Accessed on: February 22, 2017).

Altaye, S.Z., Pirk, C.W.W., Crewe, R.M., \& Nicolson, S.W. (2010). Convergence of carbohydrate-biased intake targets in caged worker honeybees fed different protein sources. Journal of Experimental Biology, 213, 3311-3318. D0l: 10.1242/jeb.046953

Anderson, K.E., Sheehan, T.H., Mott, B.M., Maes, P., Snyder, L., Schwan, M.R., ... Corby-Harris, V. (2013). Microbial ecology of the hive and pollination landscape: bacterial associates from floral nectar, the alimentary tract and stored food of honey bees (Apis mellifera). PLoS ONE, 8(12), 1-16. DOl: journal. pone.0083125

Araneda, X., Velásquez, C., Morales, D., \& Martínez, I. (2014). Producción de pan de abejas (Apis mellifera L.) bajo condiciones de laboratório. Idesia, 32(4), 6369. DOl: 10.4067/S0718-34292014000400008

Ariizumi, T., \& Toriyama, K. (2011). Genetic regulation of sporopollenin synthesis and pollen exine development. Annual Review of Plant Biology, 62, 437-460. DOl: 10.1146/annurevarplant-042809-112312

Barene, I., Daberte, I., \& Siksna, S. (2015). Investigation of bee bread and development of its dosage forms. Medicinos: Teorija ir Praktika, 27, 16-22. DOl: 10.15591/mtp.2015.003

Barreto, L.M.R.C., Funari, S.RC., \& Orsi, R.O. (2005).
Composição e qualidade do pólen apícola proveniente de sete estados brasileiros e do distrito federal. Boletim de Indústria Animal, 62(2), 167-175.

Brodschneider, R., \& Crailsheim, K. (2010). Nutrition and health in honey bees. Apidologie, 47(3), 278294. DOl: 10.1051/apido/2010012

Cappelari, F.A., Turcatto, A.P., Morais, M.M., De Jong, D. (2009). Africanized honey bees more efficiently convert protein diets into hemolymph protein than do Carniolan bees (Apis mellifera carnica). Genetics and Molecular Research, 8(4), 1245-1249. DOl: 10.4238/vol8-4gmr628

De Jong, D., Silva, E.J., Kevan, P., \& Atkinson, J.L. (2009). Pollen substitutes increase honey bee hemolymph protein levels as much as or more than does pollen. Journal of Apicultural Research, 48, 34-37. DOl: 10.3896/IBRA.1.48.1.08

Ellis, A.M., \& Hayes Jr, G.W. (2009). An evaluation of fresh versus fermented diets for honey bees (Apis mellifera). Journal of Apicultural Research, 48(3), 215-216. DOI: 10.3896/IBRA.1.48.3.11

Engel, P., \& Moran, N.A. (2013). The gut microbiota of insects - diversity in structure and function. FEMS Microbiology Reviews, 375), 699-735. DOl: 10.1111/15746976.12025

Engel, P., Kwong, W.K., McFrederick, Q., Anderson, K.E., Barribeau, S.M., Chandler, J.A., ... Dainatab, B. (2016). The bee microbiome: impact on bee health and model for evolution and ecology of host-microbe interactions. MBio American Society for Microbiology, 72), e02164-15. DOl: 10.1128/mBio.02164-15

Evans, J.D., \& Lopez, D.L. (2004). Bacterial probiotics induce an immune response in the honey bee (Hymenoptera: Apidae). Journal of Economic Entomology, 973), 752756. DOl: 10.1603/0022-0493(2004)097[0752:BPIAIR]2.0. $\mathrm{CO} ; 2$

Fuenmayor, C.A., Quicazán, M.C., \& Figueroa, J. (2011). Desarrollo de un suplemento nutricional mediante la fermentación en fase sólida de polen de abejas 
empleando bacterias ácido lácticas probióticas. Revista Alimentos Hoy, 20(23), 18-40.

Gallina, D.A., Alves, A.T.S., Trento, F.K.H.S., \& Carusi, J. (2011). Caracterização de leites fermentados com e sem adição de probióticos e prebióticos e avaliação da viabilidade de bactérias láticas e probióticas durante a vida-de-prateleira. Unopar Científica Ciências Biológicas e da Saúde, 13(4), 239-244.

Gandra, E.A., \& Gandra, T.K.V. (2007). Introdução à microbiologia de alimentos. Maringá: EDUEM.

Gilliam, M. (1979). Microbiology of pollen and bee bread: the yeasts. Apidologie, 10(1), 43-53. DOl:10.1051/apido:19790106

Herbert Jr., E.W., \& Shimanuki, H. (1978). Chemical composition and nutritive value of bee-collected and bee-stored pollen. Apidologie, 9, 33-40. DOl: 10.1051/apido:19780103

Hu, J., Lu, W., Wang, C., Zhu, R., Qiao, J. (2008). Characteristics of solid-state fermented feed and its effects on performance and nutrient digestibility in growing inishing pigs. Journal of Animal Science, 27(11), 1635-1641. DOl: 10.5713/ajas.2008.80032

Instituto Adolfo Lutz. (2008). Métodos físicoquímicos para análise de alimentos. São Paulo: Instituto Adolfo Lutz.

Kazimierczak-Baryczko, M., \& Szymaś, B. (2006). Improvement of the composition of pollen substitute for honey bee (Apis mellifera L.), through implementation of probiotic preparations. Journal of Apicultural Science, 50(1), 15-23.

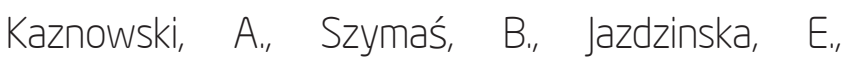
Kazimierczak, M., Paetz, H., Mokracka, J. (2005). The effect of probiotic supplementation on the content of intestinal microflora and chemical composition of worker honey bees (Apis mellifera). Journal of Apicultural Research, 44, 10-14. DOl: 10.1080/00218839.2005.11101139

Leroy, F., \& Vuyst, L.D. (2004). Lactic acid bacteria as functional starter cultures for the food fermentation industry. Trends in Food Science \& Technology, 15(2), 67-78. DOl: 10.1016/j.tifs.2003.09.004

Manning, R., Rutkay, A., Eaton, L., \& Dell, B. (2007). Lipid-enhanced pollen and lipidreduced flour diets and their effect on the longevity of honey bees (Apis mellifera L.). Australian Journal of Entomology, 46, 251-257. DOl: 10.1111/j.14406055.2007.00598.x

Martín, M.A.B., \& Cuenca, M.C.Q. (2009). Valoración de diferentes indicadores de la fermentación de bebida de soya y de leche de vaca utilizando cultivos probióticos. Brazilian Journal of Food Technology, 7, 100-106.

Morais, M.M., Turcatto, A.P., Pereira, R.A., Francoy, T.M., Guidugli-Lazzarini, K.R., Gonçalves, L.S., ... De Jong, D. (2013a). Protein levels and colony development of Africanized and European honey bees fed natural and artificial diets. Genetics and Molecular Research, 12(4), 6915-6922. DOl: 10.4238/2013

Morais, M.M., Turcatto, A.P." Francoy, T.M., Gonçalves, L.S., Cappelari, F.A., De Jong, D. (2013b). Evaluation of inexpensive pollen substitute diets through quantification of haemolymph proteins. Journal of Apicultural Research, 52(3), 119121. D0l: 10.3896/ IBRA.1.52.3.01

Nagai, T., Nagashima, T., Suzuki, N., \& Inoue, R. (2005). Antioxidant activity and angiotensin l-converting enzyme inhibition by enzymatic hydrolysates from bee bread. Zeitschrift fur Naturforschung, 60(1-2), 133-138. DOl: 10.1515/znc-2005-1-224

Nicholls, C.I., \& Altieri, M.A. (2012). Plant biodiversity enhances bees and other insect pollinators in agroecosystems. Agronomy for Sustainable Development, 33(2), 257-274. DOI: 10.1007/s13593012-0092-y

Pătruică, S., Dumitrescu, G., Stancu, A., Bura, M., Dunea, I.B. (2012). The effect of prebiotic and probiotic feed supplementation on the wax glands of worker bees (Apis mellifera). Animal Sciences and Biotechnologies, 45(2), 268-271.

Pătruică, S., \& Hutu, I. (2012). The effect of using 
prebiotic and probiotic products on intestinal microflora of the honeybee (Apis mellifera carpatica). Bulletin of Entomological Research, 102(6), 619623. DOl: 10.1017/S0007485312000144

Pătruică, S., \& Mot, D. (2013). Economic benefits of using prebiotic and probiotic products as supplements in stimulation feeds administered to bee colonies. Turkish Journal of Veterinary and Animal Sciences, 37, 259-263. DOl: 10.3906/vet$1110-20$

Pattabhiramaiah, M., Reddy, M.S., \& Brueckner, D. (2012). Detection of novel probiotic bacterium Lactobacillus spp. in the workers of Indian honeybee, Apis cerana indica. International Journal of Environmental Sciences, 2(3), 1135-1143. DOl: 10.6088/ijes.00202030002

Pereira, F.M., Freitas, B.M., Neto, J.M.V., Lopes, M.T.R., Barbosa, A.L., Camargo, R.C.R. (2006). Desenvolvimento de colônias de abelhas com diferentes alimentos proteicos. Pesquisa Agropecuária Brasileira, 47, 1-7. DOl: 10.1590/ S0100204X2006000100001

Podrižnik, B., \& Božič, J. (2015). Maturation and stratification of antibacterial activity and total phenolic content of bee bread in honey comb cells. Journal of Apicultural Research, 54(2), 81-92. DOl: 10.1080/00218839.2015.1090774

Raymann, K., Shaffer, Z., \& Moran, N.A. (2017). Antibiotic exposure perturbs the gut microbiota and elevates mortality in honeybees. PloS Biology, 15(3), 1-22. DOl: 10.1371/journal.pbio.2001861.g001

Ríos, C.A.R., Peña, Y.P., Castro, G.R., Castillo, V.L., Neninger, R.G., Cervera, Z.M. A. (2014). Optimización de la fermentación ácido láctica del polen apícola a escala de laboratório. Apiciencia: La Revista Cubana de Ciencia Apícola, 16(2), 1-14.

Ríos, C.A.R., Pérez-Piñeiro, A., Álvarez-Rivera, V.P., Rodríguez-Castro, G., Leiva-Castillo, V., Puig-Peña, Y., García-Neninger, R. (2012). Bacterias ácido-lácticas para ensilar polen apícola. Revista Cenic Ciencias Biológicas, 43, 17-21.
Rodrigues, M.I., \& lemma, A.F. (2009). Planejamento de experimentos e otimização de processos. Campinas: Casa do espírito amigo fraternidade fé e amor.

Saad, S.M.I., Cruz, A.G., \& Faria, J.A.F. (2011). Probióticos e prebióticos em alimentos. São Paulo: Varela.

Sereia, M..., Toledo, V.A.A., Furlan, A.C., Faquinello, P., Costa-Maia, F.M., Wielewski, P. (2013). Alternative sources of supplements for Africanized honeybees submitted to royal jelly production. Acta Scientiarum. Animal Sciences, 35(2), 165-171. DOl: 10.4025/ actascianimsci.v35i2.16976

Sereia, M..., Toledo, V.A.A., Faquinello, P., Costa-Maia, F.M., Castro, S.E.S., Ruvolo-Takasusuki, M.C.C., Furlan, A.C. (2010a). Lifespan of Africanized honey bees fed with various proteic supplements. Journal of Apicultural Science, 54(2), 37-49.

Sereia, M..., Toledo, V.A.A., Ruvolo-Takasusuki, M.C.C., Sekine, E.S., Faquinello, P., Costa-Maia, F.M. (2010b). Viabilidade financeira da produção de geleia real com abelhas africanizadas suplementadas com diferentes nutrientes. Acta Scientiarum, Animal Sciences, 32(4), 467-474. DOl: 10.4025/actascianimsci.v32i4.7895

Silva, N, Junqueira, V.C.A., Silveira, N.F.A., Taniwaki, M.H., Santos, R.F.S., Gomes, R.A.R. (2010). Manual de métodos de análise microbiológica de alimentos e água. São Paulo: Varela.

Siqueira, R. S. (1995). Manual de microbiologia de alimentos. Brasília: EMBRAPA.

Szymaś, B., Łangowska, A., \& Kazimierczak-Baryczko, M. (2012). Histological structure of the midgut of honey bees (Apis mellifera L.) fed pollen substitutes fortified with probiotics. Journal of Apicultural Science, 56, 5-12. D0l: 10.2478/v10289-0120001-2

Tonheim, S., Nordgreen, A., Høgøy, I., Hamre, K., Rønnestad, I. (2007). In vitro digestibility of watersoluble protein fractions of some common fish larval feeds and feed ingredients. Aquaculture, 262, 426435. DOl: 10.1016/j.aquaculture.2006.10.030 
Vamanu, E., Vamanu, A., Popa, O., \& Băbeanu, N. (2010). The antioxidant effect of a functional product based on probiotic biomass, pollen and honey. Animal Science and Biotechnologies, 43, 331336.

Vásquez, A., Forsgren, E., Fries, l., Paxton, R. J., Flaberg, E., Szekely, L., Olofsson, T. C. (2012). Symbionts as major modulators of insect health: lactic acid bacteria and honeybees. PLOS ONE, 73), 1-9. DOl: 10.1371/journal.pone.0033188 